\title{
Results study foreign varieties and agrotechniqs of buchwheat (Fagopyrum esculentum Moench)
}

\author{
Munkhjin Ganbaatar', Munkhjargal Ochirbat ${ }^{2 *}$ - (D) \\ ${ }^{1}$ Graduate School, Mongolian University of Life Sciences, Zaisan 17024, Ulaanbaatar, Mongolia \\ ${ }^{2}$ School of Agroecology, Mongolian University of Life Sciences, Zaisan 17024, Ulaanbaatar, Mongolia \\ *Corresponding author: munkhjargal_agro@muls.edu.mn
}

https://orcid.org/0000-0001-7496-9250

\begin{tabular}{lll}
\hline Received: 30.03 .2021 & Revised: 02.06.2021 & Accepted: 15.09.2021 \\
\hline
\end{tabular}

\begin{abstract}
Buckwheat is one of the most important traditional pseudocereals and a multipurpose crop, belonging to genus Fagopirum of the family Polygonaceae. Buckwheat grain grown mainly for human consumption and as animal feed, although it can also be used as a vegetable, a green manure crop, as a smother crop to crowd out weeds and as a source of buckwheat honey. Common buckwheat (Fagopyrum esculentum Moench) has been a crop of secondary importance in many countries and it has persisted through centuries of civilization and enters into the agriculture of nearly every country where cereals are cultivated. The objective of the research was to establish optimal agrotechnology including, possible varieties, vegetation period, planting space and seed quality in cultivating Fagopyrum esculentum Moench in Central cropping region of Mongolia. The results showed the chosen varieties matured around 88 to 108 days of planting and the harvest weighed 5.8-11.3 centner per hectare. Among them, the russian variety, Zyemlyachka, planted on 15th May, provided the greatest yield at 1.8-3.2 centner per hectare. Furthermore, planting the said cultivar at a distance of $30 \mathrm{~cm}$ between rows, resulted in higher yield (1.30-3.91 centner per hectare) than other alternatives. All of the chosen varieties in the study yielded high quality seeds, good grain evenness and less hulled seeds.
\end{abstract}

Keywords: common buckwheat, seed yield, number of inflorescences, seed quality

\section{Introduction}

The Government of Mongolia emphasized in its priorities, the importance of re-developing the agricultural sector, introducing the latest technologies, developing new varieties, and increasing domestic production of main agricultural products. It also emphasized the necessity of foreign and domestic projects in achieving those goals. Currently, sizeable portion of the nutritional needs of the population is being supplied through a handful of domestically produced agricultural products such as wheat, buckwheat, potatoes and other vegetables. On the other hand, as the country goes through a rapid socioeconomic transformation, people's needs too, have changed considerably, creating a demand for organic products and increase in variety in general. In order to meet that increasing market demand, numbers of agricultural enterprises as well as small and medium sized companies are seeking to find viable options for cultivating new sorts of plants such as buckwheat, sunflowers, rapes and soy etc. Buckwheat is widely cultivated in Japan, South Korea and China, and also in many South East Asian countries as well. Its relative short cultivating time and higher yields, together with its ability to survive in virtually all regions of Mongolia make it an attractive species.Buckwheat was introduced in Mongolia relatively recently in 2010, with 233 hectares of field. That has increased over the next decade, to 13300 hectares, almost 50 times the initial scale. Yields in the same period totaled 2055312tonnes, with the average yield per hectare falling between 7.7 to 13.2 centner of field. In order to develop buckwheat production on an industrial scale, it is essential to explore easily adaptable cultivars with short cultivating time and high yields, well suited to Mongolian harsh climate, alongside developing the necessary technical procedures needed in mass productions in the future. 


\section{Materials and methods}

The experiments were carried out in 2017-2019 under conditions Central cropping region (Tuv aimag, Bornuur sum, research and training center "Unjin" of MULS) of the Mongolia. The purpose of the study was to assess different varieties for buckwheat and their effects on its yield.

The soil of the test plot was typical chernozem, thick, and heavy loamy. The content of humus in the arable layer is $4.1 \%$ of mobile phosphorus (according to Churicov)- $15.6 \mathrm{mg} / 100 \mathrm{~g}$ of soil, of exchange potassium (according to Maslova) $-11.3 \mathrm{mg} / 100 \mathrm{~g}$ of soil. The reaction of the soil solution was neutral $(\mathrm{pH}$ was 6.5-7.0).

The four varieties, each coming from Russia, China, Inner Mongolia and Japan, respectively, were cultivated in three different periods (planted on May 25th, May 30th and June 5th, respectively), with two variants in each, for four replicates, resulting in 12 variants in total. Furthermore, we experimented three different versions of row distances of $30 \mathrm{~cm}$, $45 \mathrm{~cm}$ and $60 \mathrm{~cm}$, and three versions of seed rate $(2.5$ million/hectare, 3.5 million/hectare and 4.5 million/hectare) for four replicates, in 9 variants.

The visible observational changes were measured at each main growing stages. Taking samples from one square meters from each field, we have quantified

\section{Results}

The seeds germinated around 13-14 days after planting and showed no significant difference in the duration of germination process. However, some differences manifested in the stages after germination. For example, Zyemlyachka variety's growth rate was on average 8-20 days faster than the others. Fagopyrum esculentum's yield is mainly the varieties' biometrical measurements, including, number of plants (per square meters), height of the plants (centimeters), survival (percentage), number of branches (per plant), number of inflorescences (per plant), number of seeds (per inflorescences), weight of 1000 seeds (gramms) and seed yield (quintals per hectare).

This study was undertaken to determine the recovery of each components of buckwheat with or without hull by wet-milling. The aim of this work was isolation and analysis of buckwheat starch obtained by wet-milling procedure from kernels with and without hull. The starch characterization was analysed by pasting and thermal properties by using the rapid viscoanalyzer (RVA) and the differential scanning calorimetry (DSC), respectively. In addition, damage starch concentration and particle size distribution of starch granules were also assessed.

The results of the analyses are given as the means and the standard deviation of at least three independent measurements. The data were analyzed by one-way ANOVA. Fisher's Least 199 Significant Difference Test at a significance level of $p<0.05$ was performed for post-hoc 200 comparison.

determined during its flowering period.

As a result, it is essential to determine a variety's biological properties and the effects of climatic factors during this period. Buckwheat flower is very sensitive to climatic factors. And dry climate while the seed is forming in the flower, is detrimental in the ensuing seed development.

Table 1

Growing stages in selected varieties of buckwheat (Fagopyrum esculentum Moench)

\begin{tabular}{ccccccc}
\hline \multirow{2}{*}{ Varieties } & $\begin{array}{c}\text { Sowing } \\
\text { time }\end{array}$ & Germinating & $\begin{array}{c}\text { Germinating } \\
\text { to branching }\end{array}$ & $\begin{array}{c}\text { Branching to } \\
\text { flowering }\end{array}$ & $\begin{array}{c}\text { Flowering to } \\
\text { full ripeness }\end{array}$ & $\begin{array}{c}\text { Vegetation } \\
\text { period (days) }\end{array}$ \\
\cline { 3 - 7 } Zyemlyachka & $15 / \mathrm{V}$ & 13 & 20 & 30 & 25 & 88 \\
(Russia) & $25 / \mathrm{V}$ & 13 & 22 & 29 & 24 & 88 \\
& $05 / \mathrm{VI}$ & 13 & 22 & 31 & 23 & 89 \\
Yuqiao-1 & $15 / \mathrm{V}$ & 13 & 20 & 35 & 30 & 98 \\
(China) & $25 / \mathrm{V}$ & 13 & 20 & 35 & 28 & 96 \\
Limadaio & $05 / \mathrm{VI}$ & 13 & 22 & 30 & 28 & 94 \\
(Inner & $15 / \mathrm{V}$ & 13 & 22 & 34 & 39 & 108 \\
Mongolia) & 25/V & 13 & 21 & 33 & 36 & 103 \\
Kitawasesoba & 05/VI & 13 & 22 & 35 & 38 & 108 \\
(Japan) & $15 / \mathrm{V}$ & 13 & 22 & 34 & 39 & 108 \\
(Standard) & 25/V & 13 & 21 & 33 & 37 & 104 \\
\hline
\end{tabular}


According to our study, various varieties of buckwheat, on average required 23-39 days for flowering to full ripening and the process was favored by pleasant weather conditions and noted little flower drying. According to A.S.Poluyan, V.N.Gyerkovyats et al (1986), in the early stages of vegetation, high temperatures and daylight shortening from 16-13 hours a day resulted in shorter overall vegetation period, which is practically useful as it allows farmers to finish their harvest before autumn[8].

The effect of sowing time for yield capacity varieties of buckwheat

Table 2 ("Unjin" center, Bornuur sum, Tuv province, Mongolia, 2017-2019)

\begin{tabular}{|c|c|c|c|c|c|c|c|}
\hline 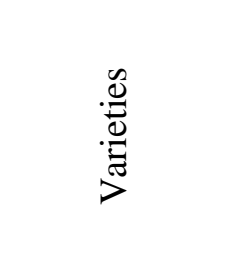 & 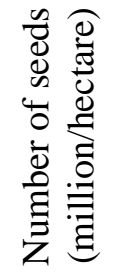 & 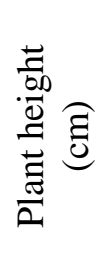 & 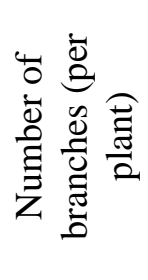 & 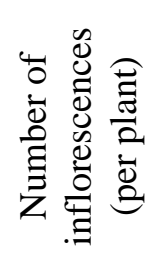 & 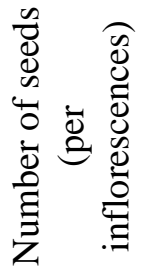 & 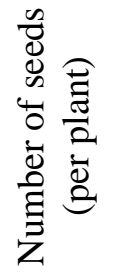 & 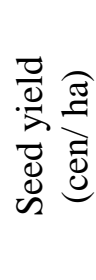 \\
\hline \multirow{3}{*}{$\begin{array}{l}\text { Zyemlyachka } \\
\text { (Russia) }\end{array}$} & $15 / \mathrm{V}$ & 86.7 & 4.7 & 26.9 & 15.7 & 586 & 11.4 \\
\hline & $25 / \mathrm{V}$ & 94.9 & 5.1 & 34.3 & 18.9 & 482 & 9.1 \\
\hline & 05/VI & 100.8 & 5.2 & 29.8 & 17.2 & 582 & 13.4 \\
\hline \multirow{3}{*}{$\begin{array}{l}\text { Yuqiao-1 } \\
\text { (China) }\end{array}$} & $15 / \mathrm{V}$ & 100.8 & 3.7 & 23.3 & 11.7 & 285 & 7.6 \\
\hline & $25 / \mathrm{V}$ & 99.1 & 3.3 & 25.6 & 11.5 & 337 & 9.7 \\
\hline & 05/VI & 90.9 & 3.3 & 17.6 & 12.6 & 281 & 6.7 \\
\hline \multirow{2}{*}{$\begin{array}{l}\text { Limadaio } \\
\text { (Inner }\end{array}$} & $15 / \mathrm{V}$ & 89.5 & 1.7 & 17.3 & 9.9 & 284 & 6.7 \\
\hline & $25 / \mathrm{V}$ & 89.1 & 1.8 & 17.0 & 10.5 & 244 & 5.3 \\
\hline Mongolian) & 05/VI & 88.8 & 1.6 & 17.6 & 10.2 & 255 & 5.4 \\
\hline \multirow{2}{*}{$\begin{array}{l}\text { Limadaio } \\
\text { (Inner }\end{array}$} & $15 / \mathrm{V}$ & 91.6 & 1.7 & 21.3 & 10.3 & 292 & 6.9 \\
\hline & $25 / \mathrm{V}$ & 90.8 & 1.6 & 20.7 & 10.3 & 278 & 5.6 \\
\hline Mongolian) & 05/VI & 92.6 & 1.8 & 22.5 & 10.9 & 282 & 6.0 \\
\hline \multirow{3}{*}{$\begin{array}{c}\text { Kitawasesoba } \\
\text { (Japan) } \\
\text { (Standard) }\end{array}$} & $15 / \mathrm{V}$ & 91.6 & 1.7 & 21.3 & 10.3 & 292 & 6.9 \\
\hline & $25 / \mathrm{V}$ & 90.8 & 1.6 & 20.7 & 10.3 & 278 & 5.6 \\
\hline & 05/VI & 92.6 & 1.8 & 22.5 & 10.9 & 282 & 6.0 \\
\hline
\end{tabular}

Munkhjargal O. (1996) showed that Krasnostryelyetskaya variety took for 116 days since planting to fully develop and had on average 5

branches/plant, 31 flowers/plant, 157 seeds/plant and 1000 of its seeds weighed $29.2 \mathrm{~g}$. Yield per hectare was 9.6 cen [6].

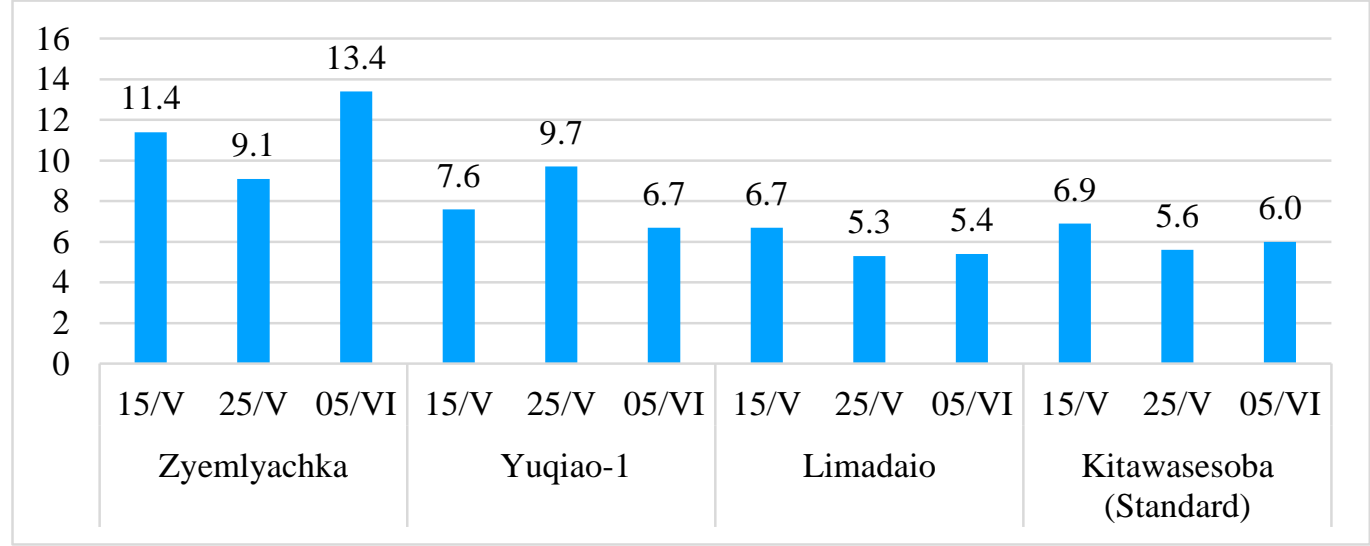

Figure1. The effect of sowing time for yield varieties of buckwheat

However, according to our research, compared to other varieties, Zyemlyachka had an average 1.6-3.3 more branches, 8.2-13.0 more inflorescence/plant, 5.3-7.2 more seeds/flower, 249-289 more seeds/plant and yielded 3.3-5.5 more cen/ha. The variety planted on June 6th, brought the greatest yield at $13.4 \mathrm{cen} / \mathrm{ha}$. 
Table 3

Effects of the seeding rate and row distances on seed yield of buckwheat (Fagopyrum esculentum Moench) ("Unjin" center, Bornuur sum, Tuv province, Mongolia, 2017-2019)

\begin{tabular}{cccccccc}
\hline $\begin{array}{c}\text { Distance } \\
\text { between } \\
\text { rows, } \\
\text { cm }\end{array}$ & $\begin{array}{c}\text { Planting } \\
\text { rate } \\
\text { (million/ } \\
\text { seeds per } \\
\text { hectare) }\end{array}$ & $\begin{array}{c}\text { Plant } \\
\text { height } \\
\text { (cm) }\end{array}$ & $\begin{array}{c}\text { Number } \\
\text { of } \\
\text { branches }\end{array}$ & $\begin{array}{c}\text { Number of } \\
\text { inflorescences } \\
\text { (per plant) }\end{array}$ & $\begin{array}{c}\text { Number of } \\
\text { seeds } \\
\text { (per } \\
\text { inflorescences) }\end{array}$ & $\begin{array}{c}\text { Number } \\
\text { of seeds } \\
\text { (per plant) }\end{array}$ & $\begin{array}{c}\text { Seed } \\
\text { yield, } \\
\text { (cen/ha) }\end{array}$ \\
\hline \multirow{2}{*}{30} & 2.5 & 106.5 & 4.5 & 29.9 & 17.9 & 545 & 11.9 \\
& 3.5 & 108.9 & 4.3 & 24.8 & 18.6 & 482 & 16.7 \\
& 4.5 & 107.9 & 5.2 & 29.7 & 16.5 & 512 & 14.8 \\
45 & 2.5 & 105.6 & 7.1 & 35.0 & 19.2 & 694 & 9.8 \\
& 3.5 & 102.1 & 5.3 & 29.0 & 17.8 & 536 & 11.9 \\
& 4.5 & 99.0 & 6.3 & 36.0 & 16.8 & 608 & 12.2 \\
60 & 2.5 & 102.7 & 5.2 & 31.7 & 22.1 & 712 & 13.9 \\
& 3.5 & 99.7 & 4.7 & 32.2 & 18.9 & 611 & 11.1 \\
& 4.5 & 96.9 & 4.3 & 26.1 & 15.9 & 400 & 14.4 \\
\hline
\end{tabular}

$\mathrm{HCP}_{0.5}=1.0 \mathrm{cen} / \mathrm{ha}$

V. Orlov and K.A.Savitsky (1967-1973) demonstrated by their research in Chaban, Ukraine that the varieties, Bogatir and Victoria gave the greatest yields at 13.3-15.9 cen/ha when planted with 2.0-3.0 million seeds/ hectare and with $45 \mathrm{~cm}$ distance between rows [7]. In another study conducted in Institute of Plant and Agricultural Sciences (2008-2010), demonstrated that among three options, the variation planted with 4.0 million seeds/ hectare on average yielded 2.0-15.9 cen/ha [2].

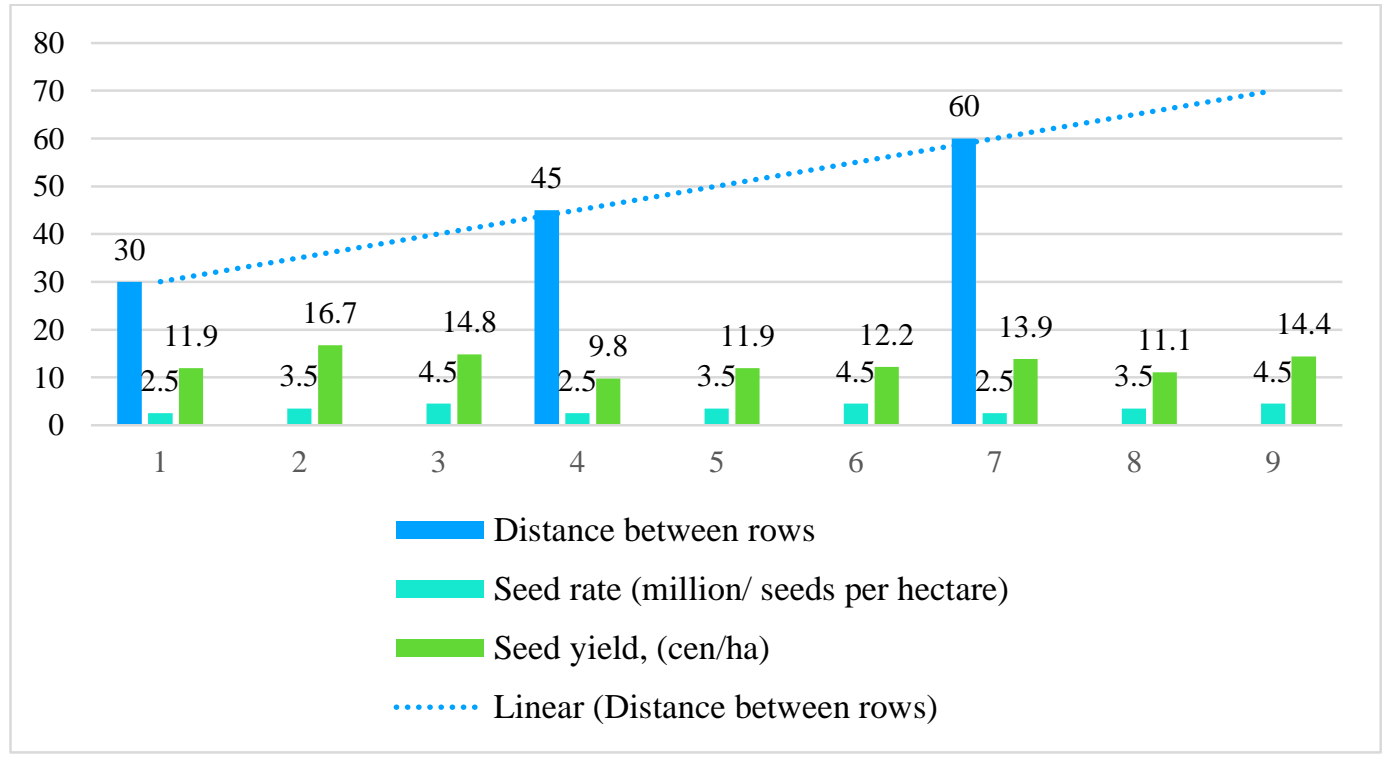

Figure 2. Effects of the seeding rate and row distances on seed yield of buckwheat

However, in our research, the Russian variety Zyemlyachka, when planted with $30 \mathrm{~cm}$ between rows and 3.5million seeds/ hectare, yielded the best, more than 1.90-6.9 cen/ha compared to other variations. The results showed that planting seeds with $45 \mathrm{~cm}$ between rows had the best results in terms of plant height, number of branches, number of flowers and most importantly, yield. This can be explained by the fact that plant roots have more space to develop unhindered by its neighbors when there is enough distance between rows. Which, in turn, allows them to absorb more water. Adequate sunshine during the vegetation period might have also been a positive influence. Main qualifiers of buckwheat varieties is their technological quality indexes which include, seed size, grain evenness etc. 
Quality indexes of the chosen varieties of buckwheat Fagopyrum esculentum Moench

Table 4 ("Unjin" centre, Bornuur sum, Tuv province, Mongolia, 2017-2019)

\begin{tabular}{llcccc}
\hline № & \multicolumn{1}{c}{ Varieties } & $\begin{array}{c}\text { Seed size } \\
(\mathrm{mm})\end{array}$ & $\begin{array}{c}\text { Grain } \\
\text { evenness, }(\%)\end{array}$ & Seed hull, \% & $\begin{array}{c}\text { Content of embyo } \\
\text { in seed, \% }\end{array}$ \\
\hline 1 & Zyemlyachka (Russia) & $3.8-4.0$ & 54.3 & 24.4 & 76.8 \\
2 & Yuqiao-1, (China) & $3.0-3.2$ & 50.5 & 28.6 & 66.4 \\
3 & Limadiao (Inner Mongolian) & $3.3-3.5$ & 48.3 & 30.2 & 58.5 \\
4 & Kitawasesoba (Japan) & $3.8-4.2$ & 52.0 & 29.5 & 68.8 \\
\hline
\end{tabular}

It can be referred from the above table that the Japanese variety, Kitawasesoba had the biggest seeds and the Russian Zyemlyachka had more grain

\section{Discussion}

Ujihara, A. (1975) proved by his experiments in Siberia and the Russian Far East, which are located between $43^{0}-60^{\circ}$ North latitude, buckwheat matures within 70-100 days as opposed to 100-130 days in India, Japan and China, which are located much further south, between the latitudes $20^{0}-30^{\circ}$ [10].

Yakimenko A.F. (1991) determined that when nutrient plot is increased from $15 \times 15 \mathrm{~cm}$ to $30 \mathrm{x} 15 \mathrm{~cm}$, the field size per flower is increased from $0.5 \mathrm{~cm}^{2}$ to $0.96 \mathrm{~cm}^{2}$ and productiveness - from 1,3 to $11,4 \mathrm{~g}[13]$.

Field experiments by Krienko A.E (1978) and Vorobev I.I (2001) in Chaban, Ukraine showed, buckwheat planted in the first 10 days of May gave higher yield of 15.3 centner per hectare, compared to different plantation periods from April 30th to June 20th.[11]

\section{Conclusion}

We make the following conclusions based on our results:

1. We have confirmed that the chosen varieties of Fagopyrum esculentum were well adapted to Mongolian soil and climate conditions and could fully develop with in 88-108 days since planting and are able to give seed yield of 6.413.6 centner per hectare on average.

2. We believe that it is desirable to plant the Russian early maturity cultivar - Zyemlyachka evenness (54.3\%), seed hull (24.4\%), content of embryo in seed (76.8\%).

Varieties Bogatir and Victoria gave the greatest yields at 13.3-15.9 cen/ha when planted with 2.5-3.0 million seed rate and with $45 \mathrm{~cm}$ distance between rows [2].

Bayarsukh N., (2001), suggested using Tatyana and I-15859 cultivars for commercial production, based on his research comparing yield and agrobiological characteristics of different cultivars in non-irrigated fields of central Mongolia. [2].

Our research showed that variety of foreign buckwheat cultivars mature relatively earlier, compared to the experiment results by previous researchers. Nadyojny-92 in particular, stands out with its early maturation in 88 days after sprouting. The cultivars used in the research gave the highest yield of 8.2 to 13.5 centner per hectare when planted in the first 10 days of May.

on May 15th, with $30 \mathrm{~cm}$ distance between rows and seeding rate of 3.5 million viable seeds per hectare.

3. We have elucidated that the Japanese Kitawasesoba cultivar had the biggest seeds and the Russian Zyemlyachka excelled in grain evenness, seed hull and content of embryo in seed. 


\section{References}

1. Arora R.K. Bukhwheat genetic resource in the Himalyas: their diversity, conservation and use. Current advance in Buckwheat Res. 1995; 1(3); 39-46

2. Bayarsukh N, "Research report defferent varieties of bukhwheat", 2001; Darkhan

3. Mthodika otsenki technologicheskikh svoistv grechikhi v processe selektsii (Manual on the Bukhwheat Technologycal Properties during Selection), Orel, 1979, pp32

4. IRGRI. Descriptors for Bukhwheat (Fagopirym spp.). International Plant Genetic Resources Institute, Rom, Italy. 1994

5. Matano T. and Ujihara A. Agroecological classfication and geographical distribution of the common bukhwheat in East Asia. JARQ 13:157162

6. Munkhjargal O., " Research report studing of varieties and sowing time of bukhwheat in the Eastern cropping region of Mongolia, RIAER, 1996;
7. Orlov V. Meteorologicheskie условия usloviya i urojai grechikhi. Zernovie i maslichnie kulturi, 1986, pp 26-29.

8. Populyan A.S. Vtoraya kulturi - Grechikha. Zernovie khozyaistvo. 1986. pp 23-25

9. Stoletova E.A, "Grechikha", 1985, Москва

10. Ujihara, A. 1975. Studies on the ecological features and the protentials as breeding materials of Asian common bukhwheat varieties (Fagopirym esculenum. M). Shinshu University Publication. Pp 75-81

11. Vorobiev I.I. 2001. Biologicheskie tekhnologi vozdelivanie grechikha na Orlovivshina, Zernovie khozyaistva, №2, -C.25

12. Ye, N. and G. Guo. Classfication, orijin and evolution of genus Fagopirum in China. pp. 1928 in proc. $5^{\text {th }}$ Int. Symp. on Bukhwheat. 20-26 August 1992, Taiyuan, China.

13. Yakimenko A.F. 1991. O sposobakh poseva grechikha, Zernovie culturii, №2, C.17 